The Third Pole: Journal of Geography

Vol. 17: 59-72, 2017

Department of Geography Education, Central Department of Education, T.U., Kathmandu, Nepal

\title{
SPATIAL VARIATION IN THE LEVEL OF AGRICULTURAL DEVELOPMENT IN DISTRICTS OF WESTERN DEVELOPMENT REGION, NEPAL
}

\author{
Bhola Nath Dhakal ${ }^{1}$
}

\begin{abstract}
In the present paper an attempt has been made to assess the spatial variation in the level of agriculture development in the Western Development Region of Nepal. Nine variables are used in determining the level of agricultural development. Those are net sown area, cropping intensity, crops productivity, irrigated area, use of High Yield Variety (HYV) seeds, chemical fertilizer (NPK) consumption, agricultural implements, agricultural labours and support from commercial and development banks. Besides, districts are classified as their respective categories viz. high, medium and low on the basis of scores (like mean and SD) of these variables. These analyses have been carried out by transforming and combining the data related to nine variables, using ' $Z$ ' score to get the composite ' $Z$ 'score. On the basis of composite score, developments of districts have been again categorized into three categories i.e. high, medium and low. On an aggregate four districts range their composite Z-score value above 0.1, are highly developed districts, six districts fall under medium category (value ranged from -0.25 to $0.1)$ and remaining six districts lie under low category having their composite Z-score below -0.25 .
\end{abstract}

Keywords: Cropping intensity, productivity, agricultural implements, Composite Index

\section{Introduction}

Nepal is a mountainous country, covering two thirds of the Himalayan region (Rokaya et al., 2012). It comprises five physiographic regions: High Mountain, Middle Mountain, Hill, the Shiwalik range and Tarai (LRMP 1986), where the main economic activities are based on agriculture. Agriculture is the major sector of Nepalese economy. It provides

1 Mr. Dhakal is a Lecturer of Geography, Ratna Rajya Campus, T.U. Kathmandu, Email:dhakalbn@gmail.com 
employment opportunities to 66 percent of the total population and contributes about 36 percent in the Gross Domestic Product (MoAD, 2014). The agriculture sector is pivotal to increase income, alleviate poverty and uplift the living standard of the people. However, the performance of this sector has been inadequate to meet the increasing food demand and livelihood needs of growing population in the country (Gauchan, 2008). Agriculture is unique and the most essential activity in every society and depends on natural and physical conditions of the area (Heston, 1993). Understanding the regional pattern of agricultural growth and development helps to evolve strategic decentralized development strategies to ensure inclusive growth in the country in the long-run (Kumar and Jain 2013).Agricultural development denotes the quality of agricultural system of a region; it is a multi-dimensional concept which mainly includes development in a real strength of cropped land, improvement in farm practices/system, improved farm implements, irrigation system and irrigated area, use of high yielding improved varieties of seeds, chemical fertilizers, insecticides and pesticides, intensity of cropping and specialization and commercialization of agriculture (Mohammed, 1980). During the past decade, agricultural development has been considered as one of the main objectives of development policies in many countries. Development policies, such as agricultural development, specifically in developing countries, are considered as the center of development projects. Considering the fact that agricultural development is a highway for improving the quality of rural life, welfare, food security and etc., balancing them with respect to levels of agricultural development necessitates categorizing and rating of districts (Moradi et al., 2015). The growth in agricultural productivity is central to development (Peter, 1988). Agricultural productivity is frequently associated with the attitude towards work, thrift, industriousness and aspirations for a high standard of living, etc. (Singh and Dhillion, 2000).

Singh (1974b) considered productivity is the degree of which the economic, cultural, technical and organizational variables are able to exploit the biotic resources of the areas for agricultural production. Conservation of physical resources is an integral part of any agricultural development (Krishan, 1992). According to Datt and Sundharam (2009), agricultural growth has a direct impact on poverty eradication, health, nutrition of rural masses, national security and multiplier effect on entire economy. A more appropriate approach might be to give a transport subsidy for fertilizer distribution in the hills and to extend credit schemes for fertilizer to small farmers in remote areas (Pearce et al., 1990). The spatial pattern of agricultural development has been measured in terms of technological factors such as chemical fertilizers (NPK), irrigation, HYV of seeds and implements (Khan \& Khalil, 2013). The level of agricultural development of an area is determined by a complex set of natural, institutional, technological and demographic forces (Patra, 2014). 
Bhola Nath Dhakal / Spatial Variation in the Level of Agricultural Development in Districts ...

The variation in altitude has resulted diverse land use pattern from southern Tarai to the Himalayas (Amatya, 1976). He has pointed out about the less intensive farming in Tarai, highly intensive in the valleys and very extensive and pastoral activities in the Himalayas that correspond to the population density.

There are several driving forces of agriculture such as demographic pressure, market integration and side by side public intervention to bring changes on farming system. The farming system in the areas with development of infrastructure is rapidly transformed. Access has led the farmers to cultivate more vegetables for marketing. For instance, agricultural knowledge and technology developed by Lumle, in Kaski district, led rapid changes in the production of vegetables, crops and livestock farming to the surrounding areas accessible to road and market. But in the areas having limited access or lack of access, farmers preferred to adopt local technology that helps to increase the local food production (Jodha et al., 1992). They also noticed that variation in agroecological condition also resulted by variations in farming system and agricultural transformation. Considering the negative impacts such as uneven development caused by the conventional development strategies of agricultural development (Karami, 1993), this paper is concerned with the identification and interpretation of spatial agricultural development patterns by employing composite index approach using data from census.

Increasing demand of agricultural crops as a result of increasing pressure of population in the one hand and modern agricultural inputs on the other made it possible to increase productivity of agricultural crops. Agriculture plays a vital role not only in the economic system of the country but also in a rural development. The low level of development and the recent concern to increase agricultural production have led to several studies concerned with various aspects of agricultural development in Nepal. Therefore, an attempt has been made to assess the spatial variation in agricultural productivity and to find out the level of agricultural development by districts in Western Development Region of Nepal.

\section{Data and Methods}

For the assessment of agricultural development, secondary data have been used. Data were collected from Statistical Information on Nepalese Agriculture, Ministry of Agricultural Development (MoAD, 2014), National Sample Census of Agriculture (CBS, 2013), Government of Nepal, Banking and Financial Statistics, Nepal Rastra Bank (2014).Tambad (1965 and 1970) has adopted crop yield index as the basis for measuring agricultural productivity. He explained that the purpose of this technique was 
to express the average yield of various crops on a farm or in a region relation to the yield of same crops on another farm or in a second region.

Agricultural productivity is defined as the "ratio of index of agricultural output to the index of total input used in farm production" (Shafi, 1984).Enyedi (1964) refers a formula for determining agricultural productivity during his geographical types of agriculture in Hungary; later Shafi (1972 and 1974) also adopted this approach to determine the productivity indices in respect of different crops. So his method was chosen to compute crop productivity for this study because of its accuracy.

In the present study to assess the spatial variation in agricultural productivity is calculated by using Shafi's method (1984). Eleven crops are selected for these studies which are paddy, wheat, maize, buckwheat, millet, potato, barley, sugarcane, oilseeds, pulses and vegetables.Shafi's method represents the summation of the total yield of all the crops in a district divided by the total area under the same crops in a district then obtained value is compared in relation to the total yield of all the crops at the regional level divided by the total area under those crops at the regional level. The Shafi's algorithm is:

$\mathrm{P}_{\mathrm{i}}=\Sigma\left(\mathrm{y}_{1} / \mathrm{t}+\mathrm{y}_{2} / \mathrm{t}+\mathrm{y}_{3} / \mathrm{t}+\ldots . . \mathrm{y}_{\mathrm{n}} / \mathrm{t}\right) /\left(\mathrm{Y}_{1} / \mathrm{T}+\mathrm{Y}_{2} / \mathrm{T}+\mathrm{Y}_{3} / \mathrm{T}+\ldots . . \mathrm{Y}_{\mathrm{n}} / \mathrm{T}\right)$

Where,

$\mathrm{P}_{\mathrm{i}}=$ Productivity index

$\mathrm{y}=$ Yield of the 1 to $\mathrm{n}^{\text {th }}$ crops at the district level.

$\mathrm{t}=$ Area under 1 to $\mathrm{n}^{\text {th }}$ crops at the district level.

$\mathrm{Y}=$ Yield of the 1 to $\mathrm{n}^{\text {th }}$ crops at the regional level.

$\mathrm{T}=$ Total area of 1 to $\mathrm{n}^{\text {th }}$ crops at the regional level.

For determining the levels of agricultural development variables such as crop productivity index, net sown area, cropping intensity, irrigated area, number of holdings under HYV use, chemical fertilizer (NPK) consumption, agricultural implements, agricultural labours and support from commercial and development banks are used (Table 1). (cited in Singh and Ashraf, 2012).

To determine the overall levels of agricultural development and its uneven distribution in the study area the data of the all variables have been transformed into indices using Z-score technique. The formula is

$$
\mathrm{Z}_{\mathrm{i}}=\frac{\mathrm{X}_{\mathrm{i}}-\overline{\mathrm{X}}}{\mathrm{SD}}
$$


Bhola Nath Dhakal / Spatial Variation in the Level of Agricultural Development in Districts ...

Where, $\mathrm{Z}_{\mathrm{i}}=$ standard score for the $i$ th observation, $\mathrm{X}_{\mathrm{i}}=$ original value of the $i$ thbservation, $\mathrm{X}=$ mean of the value of $\mathrm{X}$ variable, $\mathrm{SD}=$ standard deviation of $\mathrm{X}$ variable.

In order to classify districts according to their levels of development the composite Z-score have been grouped into high, medium and low.

Further, the result of the standard score obtained for different indicators were aggregated by composite standard score (CSS) to measure the level of development by districts. The composite standard score may be algebraically expressed as,

$$
\mathrm{CSS}=\frac{\sum \mathrm{Z}_{\mathrm{ij}}}{\mathrm{N}}
$$

Where, $\mathrm{CSS}=$ composite standard score, $\mathrm{Z}_{\mathrm{ij}}=\mathrm{Z}$ - score of an indicator $\mathrm{j}$ in block $\mathrm{i}$, and $\mathrm{N}=$ number of indicators.

In order to classify the blocks according to the magnitude of the development the composite score were divided into three classes that are high, medium and low (Aslam and Moonis, 1998).

\section{Table 1: List of selected variables}

\begin{tabular}{|c|c|c|}
\hline S.N. & Variables & Definition \\
\hline 1 & $\mathrm{X}_{1}$ & Percentage of net sown area to the gross cropped area \\
\hline 2 & $\mathrm{X}_{2}$ & Cropping intensity in percentage \\
\hline 3 & $\mathrm{X}_{3}$ & Agricultural crop productivity yield index \\
\hline 4 & $\mathrm{X}_{4}$ & Percentage of total irrigated area to gross cropped area \\
\hline 5 & $X_{5}$ & $\begin{array}{l}\text { Percentage of reporting number to number of holdings under } \\
\text { HYV. }\end{array}$ \\
\hline 6 & $\mathrm{X}_{6}$ & Chemical fertilizer (NPK) consumption $\mathrm{Kg} /$ hectare \\
\hline 7 & $\mathrm{X}_{7}$ & $\begin{array}{l}\text { Number of agricultural implements per 10,000 hectare of } \\
\text { cropping land }\end{array}$ \\
\hline 8 & $\mathrm{X}_{8}$ & Number of agricultural laborers to the total population \\
\hline 9 & $\mathrm{X}_{9}$ & $\begin{array}{l}\text { Number of commercial and development banks/ } 100,000 \\
\text { population }\end{array}$ \\
\hline
\end{tabular}




\section{Study Area}

Nepal is divided into five development regions for the development perspective representing three geographic regions from north to south. Western Development Region is one of the five development regions of Nepal. It extends from plain area of Tarai in south to Hills in middle and Mountains in north. It lies between $82^{\circ} 40^{\prime}$ to $85^{\circ}$ $10^{\prime}$ 'East longitude and between $27^{\circ} 20^{\prime}$ to $29^{\circ} 20^{\prime}$ North latitude covering $29,398 \mathrm{sq}$ $\mathrm{km}$. of surface area which has occupied $20 \%$ of total area of the country (Figure 1). The region is bounded by India in south, Mid-Western Development region in west, Central Development region in east and China in the north. The region has sixteen districts with a population of $49,26,765$ (18.6\% of total population of the country) with $10,65,699$ households (CBS, 2011). This region covers 4,82,547.4 hectares of agricultural land which gives 10 persons per hectare for agricultural land which is slightly less than national average i. e. 10.5 persons per hectare (CBS, 2013b).

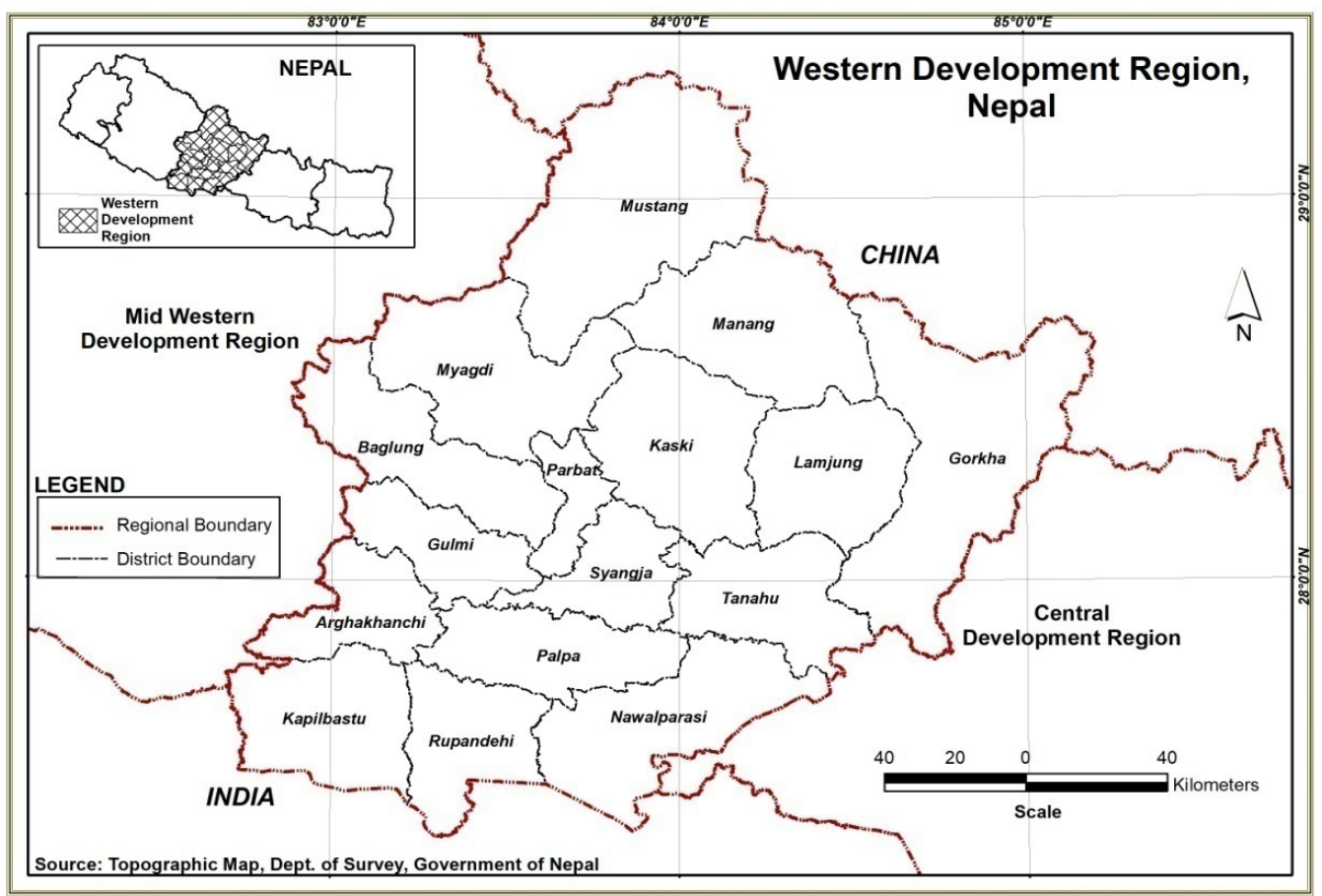

Figure 1: Location of study area 
Bhola Nath Dhakal / Spatial Variation in the Level of Agricultural Development in Districts ...

\section{Results and Discussion}

Agriculture is the main source of livelihood for millions of people in Nepal. Agricultural development is a multidimensional activity and key to rural development. It is central to all strategies of planned socio-economic development. The primary objective of agricultural development is usually to increase the growth of agricultural output to provide the livelihood to the growing population. Different variables are used to find out the level of agricultural development by districts, which are as follows:

\section{Percentage of net sown area to the gross cropped area(X1)}

The net sown area can be defined as the total area sown in a year. Higher the net sown area; higher will be the crop production and in turn will be reflected in agricultural development. It is evident from the table 2 the top position is occupied by Kapilbastu district (1.30) in net sown area (NSA). The Z-score of the districts are categorized under three groups. The high levels of NSA are in Kapilbastu (1.30), Rupandehi (1.27) and Nawalparasi (1.12). The value under high level of NSA ranges from 1.12 to 1.30 . The three out of sixteen districts fall under this category. The medium group ranges from 0.5 to 1 . There are only four districts under this category mainly Gorkha (0.82), Lamjung (0.73), Tanahu (0.67), and Myagdi (0.51). The nine districts under low NSA ranging from -1.88 to 0.51, include Kaski, Parbat, Manang, Palpa, Mustang, Syangja, Baglung, Arghakhanchi and Gulmi (with lowest value of -1.88).

\section{Cropping intensity (X2)}

The intensity of crop refers to the use of a field several times during a cropping year. It is a measure of land efficiency, which is defined as the extent to which the net area sown is cropped or sown. The value of cropping intensity is ranging from -2.76 to 1.01 in the study area. Only one district, namely Arghakhanchi (1.01) come under high category. In medium category the value ranges from 0.50 to 0.80 and seven districts, namely Nawalparasi (0.82), Syangja (0.80), Baglung (0.78), Parbat (0.75), Gulmi (0.74), Myagdi $(0.58)$ and Rupandehi (0.50). Remaining districts are under low category which ranges from -2.76 to -0.01 including Gorkha (0.01), Tanahu (-0.03), Palpa (-0.09), Lamjung (-0.39), Kapilbastu (-0.51), Kaski (-0.61), and Manang (-2.76). The lowest cropping intensity is recorded in Manang (-2.76).

\section{Crop productivity yield index (X3)}

Agricultural productivity determines the level of agricultural development in any region. It refers to per acre or hectare of yield in a unit (kgs/quintals etc.) of any crop in a region or field. A farmer adopts each kind of technique to increase the productivity 
of crop because it leads to the overall development (economic as well as social) of the farmer. The agricultural productivity of the selected crops is calculated for each sixteen districts of the Western Development Region. In order to reveal the spatial variation and to demarcate the productivity region the index value further calculated the Z-score and categorized under three groups. The value of the high productivity ranges from 0.85 to 3.33. The highest value is recorded in Baglung (3.33), in which productivity is very high, similarly Arghakhanchi (1.00) and Parbat (0.85) districts also rank in the first category. Six districts namely Myagdi, Lamjung, Syangja, Tanahu, Manang and Kaski come under medium category based on crop productivity value which is recorded from -0.18 to -0.40 . The low productivity is recorded in remaining seven districts. The lowest crop productivity is recorded in Nawalparasi and Kapilbastu districts $(-0.50)$.

\section{Percentage of Irrigated area (X4)}

Irrigation is necessary for the agricultural development and prerequisite for the success of modern technology in agriculture. The supply of water is always needed in successful farming operation. Irrigation plays a significant role in entire agriculture sector. The changing trends in the intensity of irrigation, portrays man's dynamic attempt to overcome environmental limitations to transform the potential of the area into agricultural resources (Singh, 1974).

The total irrigated area has been calculated as percent of the total sown area and further calculated Z-score of the percentage of total irrigated area. Table 2 indicates that high level of irrigation has been observed in Rupandehi (1.98), Nawalparasi (1.66) and Mustang (1.40). The medium level of irrigation has been observed only in two districts namely Kaski (0.58) and Lamjung (0.54). There are eleven districts that come under the low level of irrigation where Baglung and Gulmi districts rank in the lowest level of irrigation (-1.19).

\section{Percentage of Number of holdings under HYV seeds (X5)}

The HYV of seeds are the most important factor in agricultural production under the new technique. The success of this programme has revolutionized agriculture and brought about a phenomenal and rapid increase in the food grain production in Nepal and study region. Table 2 shows that $Z$ score values based on percentage of holdings under high yielding varieties of seeds in different districts of the Western Development Region. It has been grouped into three categories. In the high category there are only two districts, namely Kapilbastu (2.28) and Rupandehi (1.90). Similarly only two districts, Tanahu (0.78) and Nawalparasi (0.63) have been observed under medium category. Remaining 
Bhola Nath Dhakal / Spatial Variation in the Level of Agricultural Development in Districts ...

twelve districts are under low level using HYV seeds. The lowest area under HYV is observed in Palpa (-1.11) in this region.

\section{Chemical Fertilizer (NPK) Consumption (kg/hectare) (X6)}

For improving the yield rate, timely and adequate provision of inputs like fertilizer, HYV seeds and insecticides is of prime importance. Chemical fertilizers have played their crucial role in increasing food grain production and solving the problem of low yield in Nepal. The $\mathrm{Z}$ score values based on consumption of fertilizers ( $\mathrm{kg} /$ hectare) in different districts ranged from -0.85 to 2.28 . High level of $Z$ score has been recorded in districts namely Arghakhanchi (2.28), Kapilbastu (1.56) and Rupandehi (1.42). There is only one district which has medium level of consumption i.e. Nawalparasi (0.97). The low level of fertilizer consumption is recorded in remaining twelve districts of this region. The lowest valve of consumption is recorded in Myagdi and Parbat districts $(-0.85)$.

\section{Number of Agricultural implements per 10,000 hectares (X7)}

Agricultural implements are any kind of machinery used on a farm to help with farming. The use of mechanical power is necessary during scarcity of labour and relatively high wages rates particularly during the peak season. Agricultural implements are the key to the modern agricultural development. The backwardness of the Nepalese agriculture is due to their traditional agricultural system. If we use modern agricultural implements we can advance our agriculture in time saving period. The largest number of agricultural implements has been recorded in Rupandehi (2.34), Nawalparasi (2.18) and Kapilbastu (1.30) which ranges from 1.30 to 2.34. While, the districts under medium categories ranges from -0.1 to -0.5 which cover the six districts (Kaski, Tanahun, Mustang, Parbat, Syangja and Palpa) and remaining seven districts fall under low category. The lowest value of agricultural implements is noticed in Arghakhanchi district (-0.63).

\section{Number of agricultural laborers to the total population(X8)}

Like the other inputs such as chemical fertilizers, HYV seeds, machineries etc. agricultural labourers are also the important factor for agricultural development because there are many activities in the field which they perform. Table 2 indicates that the highest number of agricultural labour has been found in Kaski district (2.38). Other districts in high category are Rupandehi (1.82) and Kapilbastu (1.25). The only two districts Nawalparasi (0.33) and Manang (0.50) come under medium category of having numbers of agricultural labourer. Remaining eleven districts are under the low category. The lowest value of agricultural laborers is noticed in Arghakhanchi district (-0.95). 


\section{Role of commercial and development banks (X9)}

Commercial and development bank plays a very important role in the agricultural development. The phenomenal growth in the consumption of chemical fertilizers and other modern agricultural inputs can be made possible largely because of liberal provision of credit or loan to the cultivators by the co-operative of the government. These banks provide loan and subsidies to the farmers in term of cash or machines and tools like tractors and pump set. With the help of these facilities farmers accelerate their productivity.

Table 2 shows that commercial and development banks are not equally distributed in the study region. The high level of Z-score value ranged from 1.00 to 3.49. The highest value has been recorded in Manang (3.49) then in Mustang district (1.09). It seems that it is determined by the agricultural land and population distribution ratio. Four districts namely Rupandehi (-0.15), Kaski (-0.20), Lamjung (-0.21) and Myagdi (-0.22) ranked in medium category, and their $\mathrm{Z}$ score value ranged from -0.25 to 1 . Remaining ten districts fall under low category. The lowest value is recorded in Gulmi district $(-0.44)$.

Table 2: Standard score of the variables for the agricultural development

\begin{tabular}{lllllllllll}
\hline Districts & X1 & X2 & X3 & X4 & X5 & X6 & X7 & X8 & X9 & $\begin{array}{l}\text { Composite } \\
\text { Z Score }\end{array}$ \\
\hline Rupandehi & 1.27 & 0.50 & -0.44 & 1.98 & 1.90 & 1.42 & 2.34 & 1.82 & -0.15 & 1.1804 \\
Nawalparasi & 1.12 & 0.82 & -0.50 & 1.66 & 0.63 & 0.97 & 2.18 & 0.33 & -0.42 & 0.7545 \\
Kapilbastu & 1.30 & -0.51 & -0.50 & 0.19 & 2.28 & 1.56 & 1.30 & 1.25 & -0.42 & 0.7170 \\
Kaski & 0.33 & -0.61 & -0.38 & 0.58 & -0.21 & -0.79 & -0.06 & 2.38 & -0.20 & 0.1153 \\
Arghakhanchi & 1.53 & 1.01 & 1.00 & -1.19 & 0.09 & 2.28 & -0.63 & -0.95 & -0.40 & -0.0355 \\
Parbat & 0.14 & 0.75 & 0.85 & 0.07 & 0.23 & -0.85 & -0.45 & -0.55 & -0.30 & -0.0434 \\
Tanahu & 0.67 & -0.03 & -0.36 & -0.53 & 0.78 & -0.26 & -0.11 & -0.31 & -0.38 & -0.0576 \\
Baglung & 1.05 & 0.78 & 3.33 & -1.19 & -0.76 & -0.36 & -0.56 & -0.49 & -0.35 & -0.0712 \\
Lamjung & 0.73 & -0.39 & -0.32 & 0.54 & -0.04 & -0.64 & -0.57 & -0.58 & -0.21 & -0.1650 \\
Manang & 0.26 & -2.76 & -0.36 & -0.62 & -0.66 & -0.81 & -0.61 & 0.50 & 3.49 & -0.2321 \\
Mustang & 0.59 & -1.58 & -0.48 & 1.40 & -1.03 & -0.69 & -0.19 & -0.23 & 1.09 & -0.2557 \\
Gorkha & 0.82 & 0.01 & -0.45 & -0.19 & -0.48 & -0.51 & -0.53 & -0.85 & -0.37 & -0.2811 \\
Myagdi & 0.51 & 0.58 & -0.18 & -0.46 & -0.79 & -0.85 & -0.61 & -0.59 & -0.22 & -0.2904 \\
Syangja & 0.94 & 0.80 & -0.33 & -0.47 & -0.95 & -0.40 & -0.46 & -0.62 & -0.30 & -0.4083 \\
Gulmi & 1.88 & 0.74 & -0.45 & -1.19 & 0.11 & 0.27 & -0.59 & -0.74 & -0.44 & -0.4623 \\
Palpa & 0.35 & -0.09 & -0.44 & -0.57 & -1.11 & -0.34 & -0.47 & -0.38 & -0.42 & -0.4634 \\
\hline
\end{tabular}


Bhola Nath Dhakal / Spatial Variation in the Level of Agricultural Development in Districts ...

\section{Levels of Agricultural Development}

Nine variables have been aggregated to assess the level of agricultural development in the districts of Western Development Region. The Z-score value of nine variables is transformed and combined with the help of Z-score and composite score is prepared (Table 2). The composite score ranges from 1.1804 (highest) in Rupandehi to -0.4634 (lowest) in Palpa. Rupandehi is the most developed district in Western Development Region and Palpa is at the bottom. On the basis of composite Z-score, the districts have been categorized into three classes viz. high, medium and low which clearly show the spatial variation in level of agricultural development in Western Development Region. On an aggregate four districts namely, Rupandehi (1.1804), Nawalparasi (0.7545), Kapilbastu (0.7170) and Kaski (0.1153) which range their composite Z-score above 0.1 , are highly developed districts (Map 2)., six districts fall under medium category (value ranged from -0.25- 0.1) namely Arghakhanchi, Parbat, Tanahu, Baglung, Lamjung and Manang. Similarly remaining six districts fall under low category having their composite Z-score ranging below -0.25 . This category covers six districts namely Mustang, Gorkha, Myagdi, Syangja, Gulmi and Palpa that shows low level of agricultural development (Table 3).

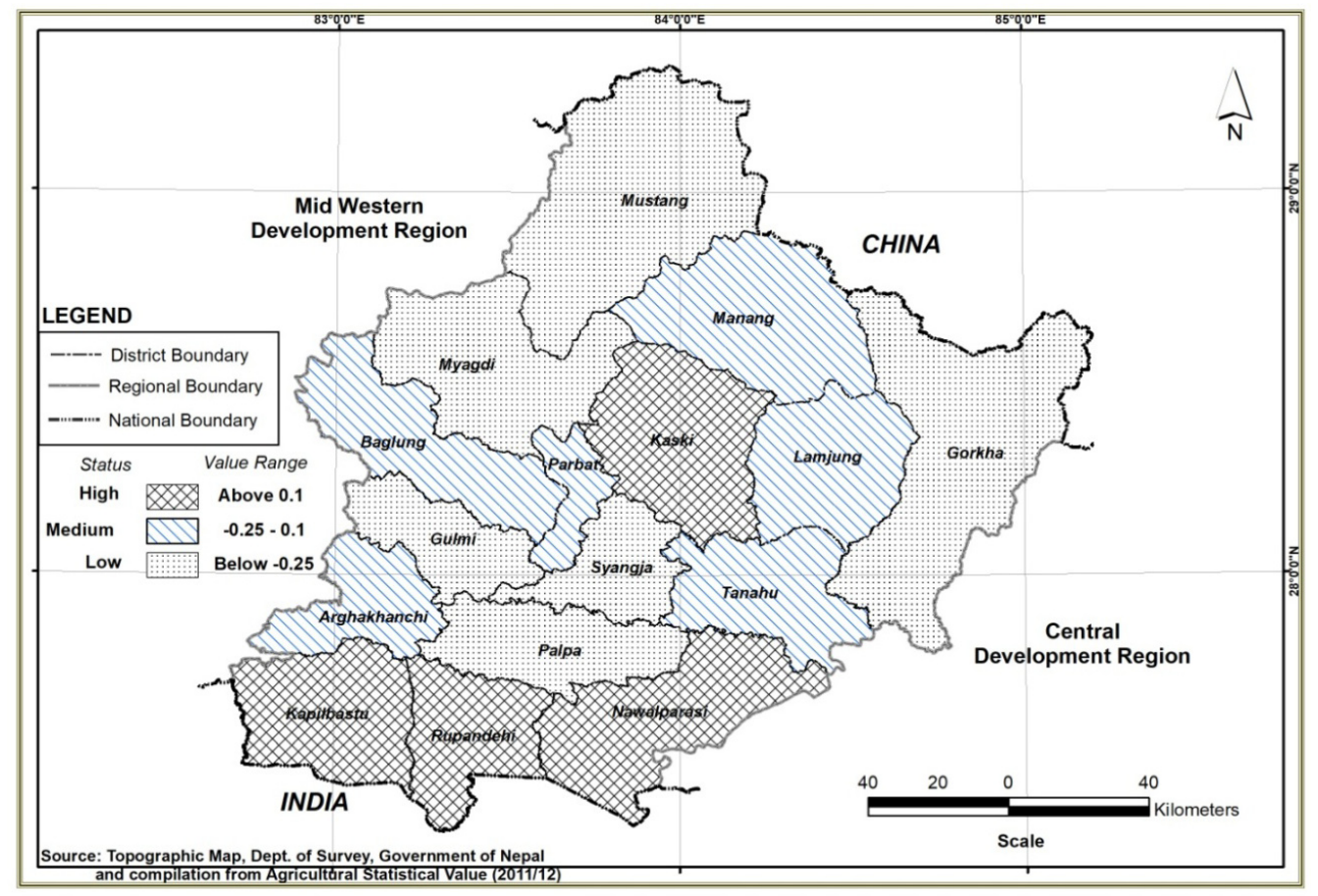

Figure 2: Levels of agricultural development based on composite Z-score 
The Third Pole: Journal of Geography, Volume 17, 2017

Table 3: The spatial pattern and the level of agricultural development

\begin{tabular}{llll}
\hline Z-score value & $\begin{array}{l}\text { Level of } \\
\text { development }\end{array}$ & Districts & Name of the districts \\
\hline 0.1 and above & High & 4 & $\begin{array}{l}\text { Rupandehi, Nawalparasi } \\
\text { Kapilbastu, Kaski }\end{array}$ \\
-0.25 to 0.1 & Medium & 6 & $\begin{array}{l}\text { Arghakhanchi, Parbat, Tanahu, } \\
\text { Baglung, Lamjung, Manang, } \\
\text { Mustang, Gorkha, Myagdi, } \\
\text { Syangja, Gulmi, Palpa }\end{array}$ \\
\hline
\end{tabular}

\section{Conclusion}

The present study reveals that the spatial distribution of variables and agricultural development is not uniform in Western Development Region. It provides very significant information about the level of agricultural development in this region. The level of agricultural development is found higher in districts lying in southern part of the study region, while the districts located on the northern High Mountain and Central Hilly areas are in medium and low level of development because of geographical location, lack of infrastructure development and low use of modern technological inputs.

Results of the aforesaid analysis show that the modern technological inputs like use of HYV seeds, use of chemical fertilizer (NPK), agricultural implements, and incentives and subsidies from banks have important relationship with agricultural development in the study area. The study highlights the impact of location and spatial input on the agricultural development planning in the study region.

\section{Reference}

Amatya, S. L. (1976). Cash crop farming in Nepal. Kathmandu: Tribhuvan University.

Aslam, M, \&Moonis, R. (1998).Statistical Methods in Geographical Studies, India: Rajesh Publications.

Central Bureau of Statistics (CBS). (2011).Population census of Nepal (2011). Kathmandu: National Planning Commission Secretariat, Government of Nepal.

CBS.(2013a).National Sample Census of Agriculture Nepal (2011/12). Kathmandu: National Planning Commission Secretariat, Government of Nepal.

CBS (2013b).Environment Statistics of Nepal. Kathmandu: National Planning Commission Secretariat, Government of Nepal. 
Bhola Nath Dhakal / Spatial Variation in the Level of Agricultural Development in Districts ...

Datt, R. \&Sundharam, K. P. M. (2009).Indian Economy. New Delhi: S. Chand \& Company Ltd.

Enyedi, G.Y. (1964). Geographical types of Agriculture, Applied Geography in Hungary, Budapest, p. 61.

Gauchan, D. (2008). Agricultural Development in Nepal: Contribution to Economic Growth, Food Security and Poverty Reduction, Socio-Economic Development Panorama, 1(3): 49-64.

Hetsen, H. (1993). Spatial Conditions for a SustainableAgriculture: RegionalDifferentiation in The Netherlands. Landscape and Urban Planning, 27: 131-139.

Jodha, N.S., Banskota, M., \&Partap, T. (1992).Startegies for the sustainable development of mountain agriculture. In N. S. Jodha, M. Baskota, \& T. Partap (Eds.), Sustainable mountain agriculture: Perspective and issues, 1: 3-40. New Delhi: Oxford \& IBH Publishing Ltd.

Karami, E. (1993). Sustainable Agriculture and Agricultural Policy, Proceedings of the Second Symposium on Agricultural Policy of Iran, Shiraz University, Shiraz. PP. 37-59.

Khan, K. \& Khalil, L. (2013). Spatio-temporal analysis of agricultural development; a block-wise study of Dehradun district, India, International Journal of Geography and Geology, 2(3):24-35.

Krishan, G. (1992). The Concept of Agricultural Development, New Delhi: Dynamics of Agricultural Development, Concept Publishing Company.

Kumar, A., \&Jain, R. (2013). Growth and Instability in Agricultural Productivity; A District Level Analysis, Agricultural Economics Research Review, 26 (31-42).

LRMP, (1986). Land Utilization Report. Land Resource Mapping Project, Kenting Earth Science Canada and Department of Topography, Government of Nepal, Kathmandu, Nepal. P. 112.

Ministry of Agricultural Development (MoAD) (2014).Statistical Information on Nepalese Agriculture, Kathmandu (2013/14): Agri-Business Promotion and Statistics Division, Agricultural Statistics Section, Singha Durbar, Government of Nepal.

Mohammed, A. (1980). Regional Imbalances in Levels and Growth of Agricultural Productivity - A Case Study of Assam.The Geographer, Aligarh Geographical Society, Aligarh, India. 
Moradi, Z. H., Mirakzadeh, A., Rostami, F. \&Karimi, F. (2015).Measuring of agricultural development levels in villages of QaraturehDehestan using TOPSIS technique. Journal of Research and Rural Planning, 4(2), 21-23.

Nepal Rastra Bank. (2014). Banking and Financial Statistics, Number 60, Kathmandu: Bank and Financial Institution Regulation Department, Statistics Division, Nepal.

Patra, R. (2014). Agricultural developments in Odisha: Are the disparities growing? International Journal of Food and Agricultural Economics, 2(3) 129-144.

Pearce, D. W., Barbier, E. B.,\&Markandya, A. (1990). Sustainable Development: Economics and Environment in the Third World, Edward Elgar and Earth scan Publications, London.

Peter, T. (1988). The agricultural transformation.Handbook of Development Economics, Elseveir, Amsterdam.

Rokaya, M. B., Muenzbergova, Z.,\&Shrestha, M. R. (2012). Distribution patterns of medicinal plants along an elevational gradient in central Himalaya, Nepal. Journal of Mountain Science, 9(2): 201-213. DOI: 10.1007/s11629-0122144-9.

Shafi, M. (1984).Agricultural Productivity and Regional Imbalance: a study of Uttar Pradesh. New Delhi: Concept Publishing Company, PP. 148-168.

Shafi, M. (1974). Perspectives on the Measurement of Agricultural Productivity, The Geographer, 21 (1): 1-10.

Shafi, M. (1972). Measurement of Agricultural Productivity of Great Indian plains, The Geographer, 19 (1): 7-9.

Singh, G. \& Ashraf, S. W. A. (2012).Spatial variation in level of agricultural development in Bulandshar district of Western Uttar Pradesh, India.International Journal of Development and Sustainability, 1(1): 47-56.

Singh, J., \&Dhillion, S. S. (2000). Agricultural Geography (Second edition) New DelhI : Tata McGraw Hill

Singh, J. (1974a). An agricultural Geography of Harayana.Kurukshetra, India: Visual Publication.

Singh, J. (1974b). The Green Revolution in India- How Green It Is?, Kurukshetra, India: Vishal Publications.

Tambad, S. B. (1965). Spatial and temporal variations in agricultural productivity in Mysore, Indian journal of agricultural economics, 20(4): 39-45. 